\title{
УДОСКОНАЛЕНА МЕТОДИКА ТА АЛГОРИТМ ОЦІНЮВАННЯ ЕФЕКТИВНОСТІ ФУНКЦІОНУВАННЯ СИСТЕМИ ПРОТИПОВІТРЯНОЇ ОБОРОНИ ТАКТИЧНОГО РІВНЯ
}

Зміни способів ведення збройної боротьби, щзо відбуваються внаслідок стрімкого розвитку засобів повітряного нападу, в тому числі безпілотних, а також авіаційних засобів ураження, обумовлюють зростання вимог до систем протиповітряної оборони. Особливо ие стосується військових формувань тактичного рівня, які складають основу для створення угруповань військ та виконання завдань ведення загальновійськового бою.

Тобто, на успіх виконання військовими формуваннями тактичного рівня завдань загальновійськового бою буде суттєво впливати ефективність функиіонування ӥх системи протиповітряної оборони. Але, на даний час, питання забезпечення відповідності результатів прогнозування реальним умовам обстановки залитається відкритими. Насамперед тому, що методики, які використовуються для очінювання ефективності функціонування системи протиповітряної оборони військових формувань тактичного рівня не є досконалими.

Так, результати аналізу положень існуючих методик оцінювання вказують на те, щуо вони не в повній мірі не призначені для тактичного рівня або не враховують особливостей підготовки $і$ ведення загальновійськового бою, а також не охоплюють зміни у концепџіях застосування засобів повітряного нападу, щзо відбулись за останній час.

Тому, зважаючи на триваючу воєнну агресію проти нашої держави, вирімення наукового завдання щцодо удосконалення методики оцінювання ефективності функціонування системи протиповітряної оборони військових формувань тактичного рівня у загальновійськовому бою, є досить актуальним.

У статті представлені загальні положення удосконаленої методики, щзо були визначені в результаті проведеного, з використанням методів системного аналізу та аналітико-стохастичного моделювання, дослідження прочесу виконання військовими формуваннями тактичного рівня завдань загальновійськового бою.

Забезпечення чутливості запропонованої методики до умов функціонування системи протиповітряної оборони в загальновійськовому бою, на відміну від існуючих, дозволить, в подальшому, на основі результатів проведення розрахунків, виробити обтрунтовані пропозиціі щчодо підвищення ефективності ї̈ функиіонування.

Ключові слова: військові формування тактичного рівня, загальновійськовий бій, система протиповітряної оборони, ефективність функціонування, оцінювання ефективності.

\section{Вступ}

Агресивні дії Російської Федерації проти України, що тривають, зміни способів ведення збройної боротьби, що відбуваються внаслідок стрімкого розвитку засобів повітряного нападу, в тому числі безпілотних, а також авіаційних засобів ураження, обумовлюють зростання вимог до систем протиповітряної оборони. Особливо це стосується військових формувань тактичного рівня, які складають основу для створення угруповань військ та виконання завдань в операції.

Постановка проблеми. В ході планування загальновійськового бою, в залежності від поставлених завдань, складу і бойових можливостей сторін, фізико-географічних характеристик району бойових дій та інших чинників, командири військових формувань тактичного рівня обирають варіант способу виконання завдань. В ньому визначається бойовий порядок формування, а також побудова відповідних систем, в тому числі системи протиповітряної оборони. Тому, успішність виконання завдань військовими формуваннями в бою, буде суттєво залежати від ефективності функціонування їх систем ППО.

Але, на даний час, в ході підготовки загальновійськового бою, питання забезпечення відповідності результатів прогнозування реальним умовам обстановки залишається відкритими. Насамперед тому, що методики, які використовуються для оцінювання ефективності функціонування системи протиповітряної оборони військових формувань тактичного рівня не $\epsilon$ досконалими. Що підтверджується результатами аналізу їх основних положень.

Тому вирішення наукового завдання щодо 
удосконалення методики оцінювання ефективності функціонування системи протиповітряної оборони військових формувань тактичного рівня у загальновійськовому бою, є досить актуальним.

Вирішення цього наукового завдання можливе за рахунок забезпечення чутливості існуючих методик до умов функціонування системи протиповітряної оборони військових формувань тактичного рівня у загальновійськовому бою.

Аналіз останніх досліджень і публікацій. Аналіз наукових праць $[1,2]$ щодо оцінювання ефективності ППО О.М. Загорки, В.П. Городнова свідчить, що результати їх досліджень складають основу для пошуку шляхів вирішення поставлених у статті завдань. Запропоновані ними методики оцінювання ефективності зенітного ракетного прикриття військ і об'єктів в операції угруповання військ ретельно вивчались та дістали подальшого розвитку в роботах Г.С. Степанова, а також, були розглянуті в роботах С.Ю. Гогонянца $[3,4]$. Але в наслідок змін, що відбулись останнім часом у способах збройної боротьби, не в повній мірі враховують проблематику військових формувань тактичного рівня (ВФ). А також, не орієнтовані на врахування специфічних властивостей ведення ними протиповітряної оборони (ППО) у загальновійськовому бою (ЗВБ), зокрема у наступальному.

Методика [5], що використовується у частинах i підрозділах ППО, викладена у додатку до Бойового Статуту військ ППО Сухопутних військ Збройних Сил України (наказ командувача СВ ЗС України від 27.12.2016 року № 596) має не тільки низку переваг, але й суттєві недоліки. Так, до переваг цієї методики можна віднести простоту проведення розрахунків та досить незначний час, що потрібний для отримання їх результатів, особливо при застосуванні засобів автоматизації. Користуватись цією методикою, після нетривалої практики, може особовий склад, що має середню та середньо-спеціальну освіту.

Але, поряд 3 цим, мається низка недоліків, які практично нівелюють вказані переваги. Так, методика не $є$ повноцінною тому, що дозволяє оцінювати тільки вогневі можливості сил і засобів (Ci3) ППО. При цьому, практично нехтує розвідувальними та маневреними можливостями. Тобто, з усіх складових частин системи ППО, в основному, розглядається тільки система зенітного ракетно-артилерійського прикриття (ЗРАП). Параметри показника ефективності, а саме математичного сподівання кількості знищених ЗПН, лише частково торкаються процесу маневру та управління вогнем. Простота розрахунків забезпечується лише при оцінюванні вогневих можливостей при витраті зенітних керованих ракет (ЗКР) та боєприпасів (БП до ЗА). А ось під час оцінювання за часовими характеристиками нальоту засобів повітряного нападу(ЗПН), зазвичай виникають складності у отримані необхідних для розрахунку даних. Також, основним критерієм оцінювання визначено процентне відношення розрахованого значення показника вогневих можливостей до його потрібного значення. Але, на якій основі цей потрібний рівень визначається, а також, яким чином розраховується не визначено [9].

Тобто, виникають протиріччя в теорії i практиці підготовки i ведення ППО ВФ та створюються передумови для збільшення необ'єктивності оцінки ефективності функціонування системи ППО. Як наслідок, прийнятя командирами (начальниками) необгрунтованих рішень. Що, в свою чергу, може привести до таких, вкрай негативних наслідків, як значні втрати від ударів 3 повітря, зниження боєздатності підрозділів ВФ та невиконання бойового завдання.

Метою статті $\epsilon$ пошук шляхів вирішення актуального наукового завдання щодо удосконалення методики оцінювання ефективності функціонування системи ППО ВФ в ЗВБ (далі методика).

\section{Виклад основного матеріалу дослідження}

Агресія Російської Федерації проти України, а також досвід збройної боротьби в останніх воєнних конфліктів в Сирії та Нагірному Карабахі вказує на те, що нездатність одної 3 сторін ефективно протидіяти загрозам 3 повітря може забезпечити як тактичну, так i стратегічну перевагу іншої сторони конфлікту $[5,6]$.

Роль і місце військових формувань тактичного рівня (ВФ) в оперативній побудові угруповання військ вищого рівня будуть визначати мету та завдання ведення ними бойових дій. При цьому, перед силами i засобами (Сi3) протиповітряної оборони (ППО) ВФ завжди буде стояти завдання знищення засобів повітряного нападу (ЗПН), збереження боєздатності та забезпечення успішного виконання підрозділами, що прикриваються, бойових завдань [7].

В ході планування загальновійськового бою (ЗВБ), в залежності від поставлених завдань, складу i бойових можливостей сторін, фізикогеографічних характеристик району бойових дій та інших чинників, командири ВФ обирають варіант способу виконання завдань. Так, наприклад для наступального бою (НБ): спосіб переходу у наступ; напрямок зосередження зусиль; порядок вогневого ураження, бойовий порядок та побудову відповідних систем, в тому числі системи ППО. Тому, успішність виконання ВФ завдань ЗВБ, буде суттєво залежати від ефективності функціонування їх системи ППО [8].

Але, на даний час, питання забезпечення відповідності результатів прогнозування реальним умовам обстановки залишається відкритими. Насамперед тому, що методики, які використовуються для оцінювання ефективності функціонування системи протиповітряної оборони військових формувань тактичного рівня не $\epsilon$ досконалими. Це підтверджується результатами аналізу положень існуючих методик оцінювання.

В статті пропонуються загальні положення удосконаленої методики, що наведені нижче. 
I. Удосконалена методика оцінювання ефективності функціонування системи ППО ВФ у ЗВБ базується на основних положеннях удосконаленої методики оцінки ефективності зенітного ракетного прикриття військ і об'єктів в операції угруповання військ $[3,4]$.

II. Методика призначена для вирішення наступних основні задач:

1.Оцінювання бойових можливостей штатних та доданих (оперативно підпорядкованих) підрозділів ППО ВФ.

2.Прогнозування втрат, що очікуються в наслідок знищення противником Сі3 ППО, а також в наслідок психогенних втрат серед особового складу.

3.Прогнозування витрати ЗКР (БП до ЗА) за етапами (завданнями) ЗВБ.

4.Оцінювання, за відповідним критерієм, обраних варіантів побудови системи ППО ВФ, в тому числі з урахуванням інших $\mathrm{Ci} 3$, що можуть бути залучені до виконання завдань ППО.

5. Обгрунтування способів ведення ППО ВФ у ЗВБ: кількісного та якісного складу Сi3 ППО, бойових порядків, інтенсивності маневру, необхідних запасів та витрати ЗКР (БП до ЗА) для досягнення потрібних бойових можливостей; побудови системи управління (склад та кількість ланок управління, визначення способів управління вогнем для досягнення потрібних бойових можливостей тощо); склад Сi3 РПП, визначення можливостей щодо своєчасного виявлення ПЦ та видачу їі у потрібному вигляді споживачам.

6. Прогнозування ефективності функціонування системи ППО ВФ за етапами(завданнями) ведення ЗВБ обраним способом.

III. Вихідними даними для проведення розрахунків за удосконаленою методикою $\epsilon$ результати проведення оцінювання обстановки, що здійснюється командирами (начальниками) в ході планування ЗВБ [9].

1. Щодо противника: головний напрямок; можливості i рубежі досяжності ракетних i артилерійських засобів; очікувану кількість і типи ЗПН противника під час удару по ВФ; діапазони висот польоту та основні напрямки ударів; можливості щодо постановки перешкод; рубежі застосування АЗУ; приховані напрямки нальотів повітряних цілей при мінімальній дальності виявлення на заданій висоті; очікувані щільності удару за етапами (завданнями) ЗВБ та підльотний час ЗПН противника.

2. Щодо підрозділів (об'єктів) ВФ, що прикриваються: місце та важливість підрозділів, що прикриваються, в бойовому порядку ВФ за етапами(завданнями) ЗВБ; на якому етапі (при виконанні яких завдань) ЗВБ та по яких об'єктах слід очікувати удари ЗПН противника; на якому етапі (при виконанні яких завдань) ЗВБ та на прикритті яких підрозділів і об'єктів ВФ слід зосереджувати основні зусилля з ППО.

3. Щодо Сі3 ППО ВФ: укомплектованість та стан особового складу; укомплектованість та стан озброєння та техніки (ОВТ); наявні запаси ЗКР(БП до 3А) та інших матеріально-технічних засобів(МТ3); потенційні розвідувальні, вогневі та маневрені можливості ОВТ підрозділу; можливості щодо захисту від перешкод та ВТЗ противника;

4. Щодо взаємодіючих Сi3 ППО (сусідніх, старшого начальника, інших видів 3С України тощо): склад та бойові можливості; яким чином, на яких етапах (при виконанні яких завдань) ЗВБ та 3 яких стартових позицій (СП) можуть підсилити ЗРАП ВФ.

5. Щодо району ведення бойових дій: розміри визначеного району; фізико-географічні умови (захисні властивості місцевості, іiі прохідність і оглядність, наявність природних перешкод, якість дорожньої мережі та можливість іiі використання для ведення розвідки та вогню); пору року та час доби.

6. Щодо радіоелектронної обстановки: можливості противника щодо радіоелектронної розвідки (РЕР) та радіоелектронного придушення (РЕП) СіЗ ППО ВФ за етапами(завданнями) ЗВБ.

IV. В методиці пропонується використовувати удосконалену систему показників оцінювання ефективності системи ППО ВФ, що була запропонована у попередніх публікаціях [10].

Основу цієї системи складають математичне сподівання кількості ЗПН, що знищуються в ході виконання завдань 3 прикриття підрозділів i об'єктів ВФ $\left(M^{y p .3 П Н}\right)$ та математичне сподівання кількості знищених противником ЦК, за час бою $\left(M^{3 н . Ц К}\right)$.

Загальні математичні вирази для їх розрахунку наведені нижче.

Математичне сподівання загальної кількості знищених у ЗВБ ЗПН противника може бути розраховане за формулою[10]:

$$
M_{\text {звб }}^{\text {yp.3ПН }}=\sum M_{i}^{y p .3 П н}\left(t_{i}\right), i=1, N_{e m}
$$

де $N_{e m}$ - кількість етапів(завдань) за обраним способом ведення ЗВБ;

$i$ - індекс відповідного етапу(завдання) ЗВБ;

$M_{i}{ }^{y p .3 П н}-$ математичне сподівання кількості знищених ЗПН за час виконання і-го бойового завдання (на і-му етапі ведення) ЗВБ.

При цьому [10]:

$$
M_{i}{ }^{y p .3 \Pi H}\left(t_{i}\right)=N_{i j}{ }^{c m p} P_{i j}{ }^{n} K_{i j}{ }^{2 o m}, j=1, N_{u \kappa},
$$

де $N_{u \kappa}$ - кількість типів ЦК, що призначені для виконання завдань ППО на і-му етапі (завданні) ЗВБ за обраним способом його ведення;

$j$ - індекс відповідного типу ЦК;

$N_{i j}{ }^{c m p}$ - математичне сподівання середньої кількості стрільб ЦК ј-го типу в ході ведення протиповітряних боїв на і-му етапі (завданні) ЗВБ тривалістю ti;

$$
P_{i j}{ }^{n}-\text { середня ефективність стрільби ЦК ј-го }
$$


типу призначеною на і-му етапі (завданні) ЗВБ кількістю ЗКР;

$K_{i j}^{\text {гот }}$ - коефіцієнт, що враховує готовність ЦК ј-го типу до виконання завдань на i-му етапі (завданні) ЗВБ.

Математичне сподівання кількості знищених противником ЦК [10] може бути розраховане за формулою:

$$
M_{i j}^{3 н . Ц \kappa}\left(t_{i}\right)=n_{i j}{ }^{u \kappa} P_{i j}{ }^{u \kappa}\left(t_{i}\right)
$$

де $P_{i j}{ }^{u \kappa}\left(t_{i}\right)$ - середня ймовірність ураження противником ЦК ј-го типу на і-му етапі (завданні) ЗВБ.

Основними перевагами обраної системи показників $\epsilon$ : більш ясний фізичний зміст; чутливість до змін умов функціонування системи ППО ВФ та їі основних параметрів, за етапами (завданнями) ведення ЗВБ. Крім того, дана система показників дає можливість здійснювати порівняльне оцінювання обраних варіантів побудови системи ППО у відповідності до дій підрозділів, що прикриваються $[10,11]$. При цьому, при проведенні розрахунків обробляється сукупність з більше ніж 50-ти параметрів щодо сил і засобів противника, а також щодо ВФ та їх сил і засобів ППО.

V. Основним критерієм оцінювання ефективності функціонування системи ППО ВФ в
ЗВБ $є$ : досягнення максимального значення математичного сподівання кількості знищених ЗПН на і-му етапі (завданні) ЗВБ $-M_{i}{ }^{\text {p. } 3 П Н}$. За умови забезпечення допустимого рівня втрат ЦК, що визначається математичним сподіванням кількості знищених противником ЦК на і-му етапі

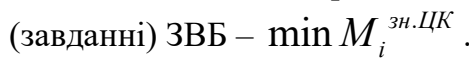

Тобто, для оцінювання прийнятності рішень за прогнозованими значеннями обраних показників, застосовується правило:

$$
\begin{aligned}
& M_{i}^{\text {pp.3ПH }} \geq M_{i y p .3 П H}^{\text {nomp }},
\end{aligned}
$$

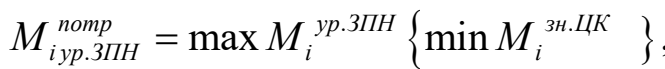

де $M_{i}{ }^{y p .3 \Pi н}$ - математичне сподівання кількості знищених ЗПН на і-му етапі (завданні) ЗВБ;

$M_{\text {iур.3пн }}^{\text {nomp }}$ - математичне сподівання потрібної кількості знищених ЗПН на і-му етапі (завданні) ЗВБ;

$$
M_{i}^{\text {зн.ЦК }} \text { - математичне сподівання кількості }
$$
знищених противником ЦК на і-му етапі (завданні) ЗВБ.

VI. Структурно-логічна схема удосконаленої методики оцінювання функціонування системи ППО ВФ представлена на рисунку 1.

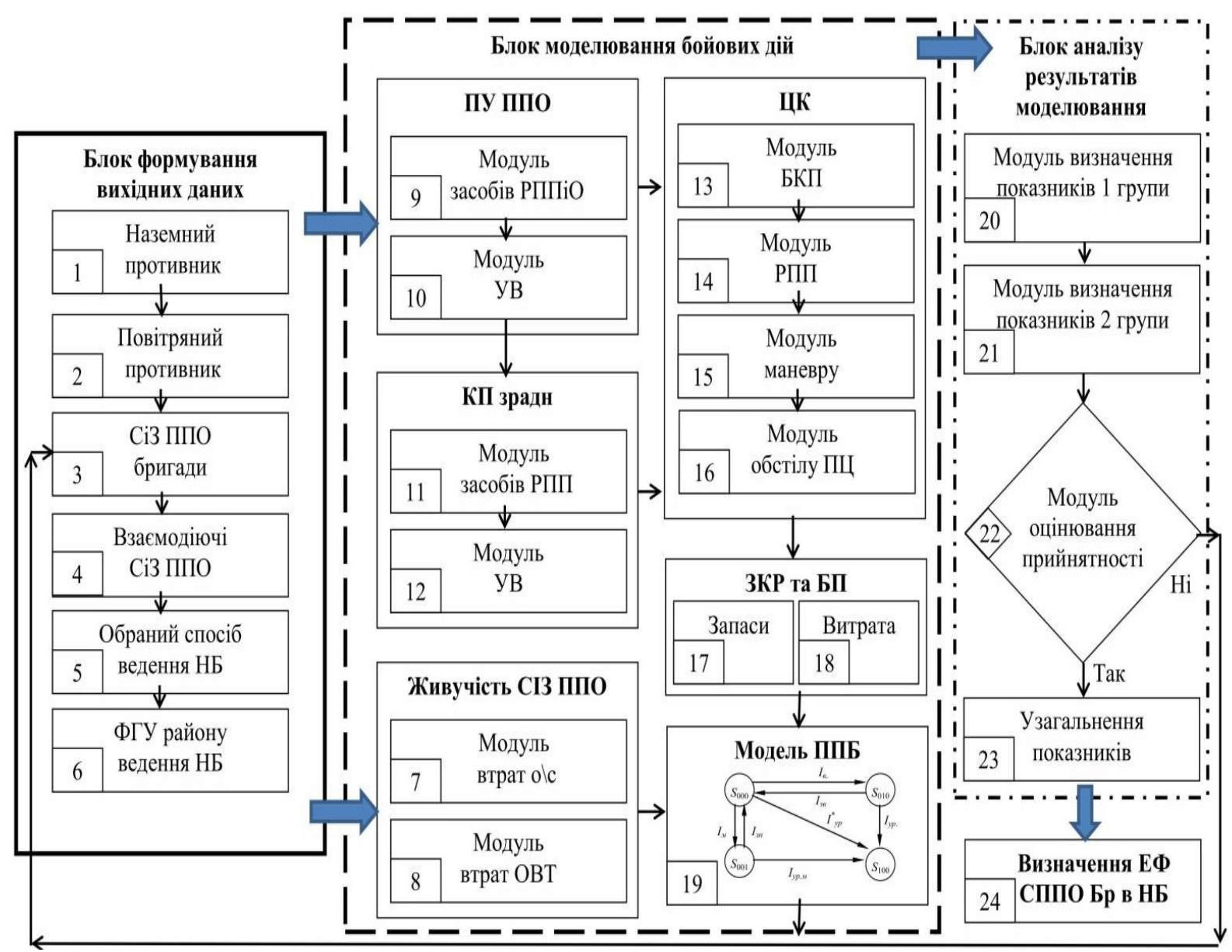

Рис. 1 Структурна схема методики 
Інформація, що необхідна для проведення попередніх розрахунків та моделювання, міститься у блоці формування вихідних даних.

У субблоці №1 "Наземний противник" визначаються: кількісно-якісний склад наземних угруповань противника; характеристики основних зразків озброєння ракетних військ і артилерії (РВіА) та притаманні їм особливості застосування, a саме рубежі досяжності засобів РBiA та можливості щодо вогневого ураження; склад наземних Сi3 радіоелектронної бородьби (РЕБ) та ïх можливості щодо радіоелектронного придушення (РЕП) елементів системи ППО ВФ.

У субблоці №2 "Повітряний противник" визначається масштаб і характер дій повітряного противника(ПП), а саме: склад, стан, базування ЗПН, можливості щодо нанесення ударів, наявність авіаційних засобів РЕБ та можливості щодо РЕП елементів системи ППО ВФ; рубежі досяжності ЗПН, висоти польоту, підльотний час, можливі об'єкти та сила ударів, рубежі виконання завдань (застосування авіаційних засобів ураження (АЗУ), засобів РЕБ тощо).

У субблоці №3 "Сi3 ППО ВФ" визначається склад (підрозділи, кількість та основні тактикотехнічні характеристики (ТТХ) штатного ОВТ за типами цільових каналів (ЦК)), стан (укомплектованість та технічний стан ОВТ, укомплектованість та готовність особового складу до виконання завдань, наявні запаси ЗКР та БП) та потенційні бойові можливості Сi3 ППО ВФ, що можуть бути залучені до виконання завдань ППО ВФ під час підготовки і ведення наступального бою.

У субблоці №4 "Взаємодіючі Сi3 ППО" визначається: склад, положення, бойові можливості, завдання, що виконуються та можливість залучення до виконання завдань ППО ВФ під час підготовки і ведення наступального бою.

У субблоці №5 "Обраний спосіб ведення ЗВБ" у відповідності до обраного командиром варіанта способу дій визначаються: кількість, важливість та особливості (розмір, рухливість, захищеність) об'єктів прикриття, варіанти побудови системи ППО ВФ за етапами ведення наступального бою. А саме: склад, можливості щодо управління підрозділами та вогнем, положення та завдання пунктів управління ППО; склад, можливості, положення та завдання Сі3 для ведення розвідки ПП і оповіщення про його дії (РППіО); розподіл Ci3 ППО за об'єктами прикриття, їх бойовий порядок та систему вогню.

У субблоці №6 "ФГУ району ведення ЗВБ" визначаються основні фізико-географічні умови (ФГУ) та інші характеристики району ведення бойових дій, що можуть впливати на побудову i функціонування системи ППО ВФ: просторові розміри, погодні умови, рельєф та середні значення розміру місцевих предметів, дорожня мережа та іiі прохідність, наявність бар'єрних рубежів та небезпечних ділянок (забруднень, пожеж, дій ДРС тощо).
У блоці моделювання бойових дій, на основі значень основних параметрів системи ППО ВФ, що вироблені у блоці формування вихідних даних, моделюється функціонування іiі основних підсистем (елементів). При цьому використовується удосконалена модель протиповітряного бою (ППБ) та декілька удосконалених часткових методик, а саме: визначення необхідних запасів та витрати ЗКР (БП до 3А), а також визначення способів управління вогнем.

У модулі "Втрати Сi3 ППО" за наявними даними про можливості нанесення противником вогневого ураження по об'єктах ВФ в ході підготовки і ведення ЗВБ прогнозуються втрати Ci3 ППО. При цьому, в субблоці 7 "Втрати olc" прогнозуються втрати особового складу, в тому числі психогенні. А в субблоці 8 "Втрати ОВТ" прогнозуються втрати ОВТ. Слід зазначити, що до уваги беруться лише ті Сi3, що суттєво впливають на функціонування системи ППО у ЗВБ.

У модулях "ПУ ППО" та "КП зрадн" за даними висновків з оцінювання ПП, своїх та взаємодіючих Ci3 ППО, а також обраного способу ведення ЗВБ моделюється робота відповідного пункту управління. Як для пункту управління ППО ВФ (ПУ ППО), так і для командного пункту (КП) зенітного ракетно-артилерійського дивізіону (зрадн) оцінюються можливості щодо своєчасного отримання інформації про повітряну обстановку, яка необхідна для прийняття рішень, обробку та видачу іï у потрібному вигляді споживачам. При цьому, як у субблоці 9 "РППіО", так і субблоці 11 "РППіО", вказаних модулів оцінюються можливості щодо своєчасного виявлення ЗПН засобами розвідки. А в субблоках 10, 12 "БР та УВ" оцінюється можливості щодо своєчасного прийняття рішень на ведення вогню та постановки завдань підпорядкованим Сi3.

У модулі "ЦК" за даними висновків 3 оцінювання ПП та своїх Сі3 ППО оцінюється можливість виконання ЦК завдань щодо обстрілу ПЦ. У субблоці 14 "РПП" оцінюються можливості ЦК щодо своєчасного виявлення ЗПН засобами розвідки. У субблоці 15 "Маневр" оцінюються можливості ЦК щодо здійснення маневру. У субблоці 16 "Обстріл ПЦ" оцінюються можливості ЦК щодо обстрілу ПЦ по якій поставлено завдання.

Слід зазначити, що з сукупності модулів "ПУ ППО", "КП зрадн" та "ЦК" складається новий елемент структурно-логічної схеми удосконаленої методики, який визначає доцільність способів управління вогнем ЦК. Тобто, в цілому, результати роботи цих модулів дозволяють оцінити можливість ЦК щодо обстрілу певної кількості ПЦ за обраним видом цілерозподілу (ЦР).

Поєднання субблоків 17 "Запаси" та 18 "Витрата" у модулі "ЗКР та БП" дозволяє в ході оцінювання за удосконаленою методикою визначати, на відміну від базової методики, не тільки призначену витрату ЗКР ( БП до ЗА) тобто 
призначені види вогню ЦК, а ще й необхідний запас ЗКР ( БП до ЗА) для досягнення необхідних результатів ведення ППБ.

Результати, що отримані у вказаних раніше модулях вносяться до модуля 19 "Модель ППБ" в якій моделюється ведення ЦК протиповітряного бою в конкретних умовах підготовки і ведення (етапу) ВФ ЗВБ за обраним способом. В результаті моделювання отримуються значення обраної системи показників оцінювання ефективності (ПОЕ) функціонування системи ППО ВФ в ЗВБ.

В подальшому, у відповідності до поставлених завдань $з$ протиповітряної оборони в модулях 20 та 21, визначаються потрібні значення першої та другої групи ПОЕ функціонування системи ППО ВФ в ЗВБ відповідно.

Після чого в модулі 22 "Модуль оцінювання прийнятності" визначається відповідність результатів моделювання поставленим завданням. Тобто порівнюються значення отриманих значень ПОЕ 3 потрібними. Та, у залежності від результатів порівняння, здійснюється перехід або до подальших операцій і завершення оцінювання, або повернення до початку роботи для внесення відповідних змін у прийняті рішення.

У разі прийнятності отриманих значень ПОЕ у субблоці 23 проводиться узагальнення результатів та у субблоці 24 здійснюється визначення ефективності функціонування обраної побудови системи ППО ВФ в ЗВБ за обраним способом.

\section{Висновки й перспективи подальших досліджень}

Таким чином, враховуючи результати проведеного аналізу умов функціонування системи ППО ВФ в ЗВБ, були визначені загальні положення методики, для удосконалення якої, було вирішено завдання щодо отримання можливостей враховувати закономірності впливу обраних способів виконання ВФ завдань ЗВБ на побудову їх системи ППО. Так, крім параметрів,

\section{Лimepamypa}

1. Загорка О. М. Методичні положення оцінки живучості зенітної ракетної системи від дії по іiї елементах засобів ураження противника / О. М. Загорка, В. В. Коваль, І. О. Загорка // Збірник наукових праць Харківського університету Повітряних Сил. - 2017. - № 4. - С. 12-16. 2. Городнов В.П. Моделювання бойових дій військ (сил) протиповітряної оборони та інформаційне забезпечення процесів управління ними (теорія, практика, історія розвитку) / В.П. Городнов [та ін.] ; Харківський військовий ун-т. - Харків. : ХВУ, 2004. - 410 с. - ISBN 966-601-071-2. 3. Гогонянц С.Ю. Удосконалена аналітико-стохастична модель протиповітряного бою зенітного ракетного комплексу /, В.П. Городнов, С.Ю. Гогонянц // Сучасні інформаційні технології у сфері безпеки та оборони // НУОУ - К, 2010. - №2 (8) - С. 47 - 54. - Режим доступу: http://nbuv.gov.ua/UJRN/sitsbo_2010_2_3.

4. Гогонянц С.Ю. Удосконалена методика оцінки ефективності протиповітряної оборони військ та об’єктів [Текст] / Г.С. Степанов, С.Ю.Гогонянц // Матеріали науково-практичного семінару “Інформаційні технології у військовій сфері”, Тез. доп. - Київ: НУОУ, 2010. - С. 49-52. 5. Біла книга антитерористичної що приймались до уваги раніше, було забезпечено чутливість до впливу обраних способів управління вогнем та маневру, створених запасів ЗКР (БП) та психогенних втрат особового складу. Також, удосконалено структурно-логічну схему методики та передбачено можливість оцінювання ефективності системи ППО за відповідними етапами(завданнями) обраного способу ведення ЗВБ.

Слід зазначити, що травні 2021 року, під час проведення у Національному університеті оборони України імені Черняховського командно-штабного навчання $з$ слухачами випускних курсів, в ході якого досліджувались можливості частин i підрозділів ППО щодо прикриття ВФ від ударів 3 повітря, було проведено апробацію застосування удосконаленої методики, загальні положення якої наведені у даній статті. При цьому, для проведення розрахунків було використано створену на командно штабних-навчаннях оперативно-тактичну обстановку. В тому числі кількісно-якісний склад сил і засобів ППО.

Результати апробації показали, що запропонована у статті удосконалена методика, на відміну від існуючої, більш адекватна умовам підготовки i ведення загальновійськового бою військовими формуваннями тактичного рівня. А також, вже на цьому етапі досліджень, забезпечує більшу чутливість до параметрів функціонування системи ППО ВФ, тобто до параметрів кожної 3 підсистем: розвідки ПП і оповіщення, управління та ЗРАП.

Тому, з подальшим розвитком іiі положень, дана удосконалена методика дозволить отримувати більш об'єктивні результати прогнозування й буде забезпечувати командирам (начальникам) можливості обгрунтовувати пропозиції щодо підвищення ефективності функціонування системи ППО ВФ у загальновійськовому бою.

операції на Сході України (2014-2016) / (під заг. ред. I. Руснака) - К.: Національний університет оборони України імені Івана Черняховського, 2017. - 162 с. ISBN 978-617-7187-21-8. 6. Офіційний сайт Deutsche Welle. Війна Вірменії та Азербайджану за Карабах: що приніс місяць боїв. - Режим доступу: https:/www.dw.com/uk/viina-virmenii-ta-azerbaidzhanu-zakarabakh-shcho-prynis-misiats-boiv/a-55423675

(15.10.2021). - Назва 3 екрану. 7. Бернадський Б.В. Міжнародні конфлікти: курс лекцій / Б.В. Бернадський. - К.: ДП «Вид. дім «Персонал», 2012. - 366 с. — ISBN 978-617-02-0088-4. 8. Аналіз форм і способів застосування Сухопутних військ в сучасних умовах, які впливають на розвиток ОВТ, засоби технічного забезпечення, підготовки технічних спеціалістів [Електронний ресурс] / М.М. Середенко, Р.В. Кузьменко, Р.В. Хорєв, Л.М. Кізло, — Львів: НАСВ, 2017. - Режим доступу: https://www.ukrmilitary.com/2017/09/analysis-forms-andmethods.html (15.05.2021). - Назва з екрану. 9. Бойовий статут військ протиповітряної оборони Сухопутних військ, частина III - К: КСВ ЗС України, 2016. - 142 с. 10. Горбачов К.М. Удосконалена система індикаторів 
ефективності функціонування системи протиповітряної оборони військового формування тактичного рівня в наступальному бою / К.М.Горбачов // Journal of Scientific Papers "Social Development and Security", Vol. 11, No. 5, October, 2021, P. 81-89. DOI: https://doi.org/10.33445/sds.2021.11.5.8, ISSN 25229842. 11. Spartak Hohoniants. Development of the survivability indicators forecasting method of the specialpurpose system executive element based on analytical and stochastic simulation of a conflict situation. / Spartak Hohoniants, Kostiantyn Horbachov, Dmytro Chopa, Oleksii Kilmeninov, Anatolii Loishyn // Eastern-European Journal of Enterprise Technologies. 2021. Vol. 3 No. 4 (111). P. 1423. https://doi.org/10.15587/1729-4061.2021.233899

\title{
УСОВЕРШЕНСТВОВАННАЯ МЕТОДИКА ОЦЕНИВАНИЯ ЭФФЕКТИВНОСТИ ФУНКЦИОНИРОВАНИЯ СИСТЕМЫ ПРОТИВОВОЗДУШНОЙ ОБОРОНЫ ТАКТИЧЕСКОГО УРОВНЯ
}

\author{
Константин Николаевич Горбачев
}

\author{
Национальный университет обороны Украины имени Ивана Черняховского, Киев, Украина
}

Изменение способов ведения вооруженной борьбы, которые происходят в следствии стремительного развития средств воздушного нападения, в том числе беспилотных, а также авиаиионных средств поражения, обуславливают рост требований к системам противовоздушной обороны. Особенно это касается военных формирований тактического уровня, составляющих основу для создания группировок войск и выполнения задач ведения общевойскового боя.

То есть, на успех выполнения военными формированиями тактического уровня задач общевойскового боя будет существенно влиять эффективность функиионирования системы противовоздушной обороны. Но, в настоящее время, вопрос обеспечения соответствия результатов прогнозирования реальным условиям обстановки остается открытым. Прежде всего, потому, что методики, используемые для оценки эффективности функционирования системы противовоздушной обороны военных формирований тактического уровня, не совериенны.

Так, результаты анализа положений существующих методик оценивания указывают на то, что они не в полной мере предназначены для тактического уровня или не учитывают особенности подготовки и ведения общевойскового боя, а также не охватывают изменения в концепциях применения средств воздушного нападения, которые произошли за последнее время. Поэтому, учитывая продолжсаюшуюся военную агрессию против намего государства, решение научной задачи по усовершенствованию методики оценки эффективности функиионирования системы противовоздушной оборонь военных формирований тактического уровня в общевойсковом бою является весьма актуальным. В статье представлены общие положения усовершенствованной методики, которые были определенны в результате исследования прочесса выполнения военными формированиями тактического уровня задач общевойскового боя.

Обеспечение чувствительности предложенной методики к условиям функиионирования системы противовоздушной обороны в общевойсковом бою, в отличие от уже существующих, позволит в дальнейшем на основе результатов проведения расчетов производить обоснованные предложения по повышению эффективности ее функиионирования.

Ключевые слова: военные формирования тактического уровня, общевойсковой бой, система противовоздушной обороны, эффективность функиионирования, оценивание эффективности.

\section{IMPROVED METHOD OF EVALUATING THE EFFICIENCY FUNCTIONING OF THE TACTICAL LEVEL AIR DEFENSE SYSTEM}

\author{
Konstiantyn Horbachov
}

\section{National Defence University of Ukraine named after Ivan Cherniakhovskyi, Kyiv, Ukraine}

Changes in the methods of warfare, which are taking place as a result of the rapid development of air attack weapons, including unmanned ones, as well as aircraft weapons, cause an increase in the requirements for air defense systems. This is especially true for military formations of the tactical level, which form the basis for the creation of groupings of troops and the implementation of tasks for conducting combined arms combat.

That is, the effectiveness of the functioning of the air defense system will significantly affect the success of military formations in the implementation of the tactical level tasks of combined arms combat. But, at present, the question of ensuring the correspondence of the forecasting results to the real conditions of the situation remains open. First of all, because the methods used to assess the effectiveness of the functioning of the air defense system of military formations at the tactical level are not perfect.

Thus, the results of the analysis of the provisions of the existing assessment methods indicate that they are not fully intended for the tactical level or do not take into account the peculiarities of the preparation and 
conduct of combined arms combat, and also do not cover the changes in the concepts of using air attack weapons that have occurred recently. Therefore, taking into account the ongoing military aggression against our state, the solution of the scientific task of improving the methodology for assessing the effectiveness of the functioning of the air defense system of military formations of the tactical level in a combined arms battle is very urgent. The article presents the general provisions of the improved methodology, which were determined as a result of the study of the process of performing the tasks of combined arms combat by military formations at the tactical level.

Ensuring the sensitivity of the proposed methodology to the operating conditions of the air defense system in combined arms combat, in contrast to the existing ones, will allow in the future, based on the results of calculations, to make reasonable proposals to improve the efficiency of its functioning.

Key words: tactical level military formations, combined arms operation, air defense system, functioning efficiency, efficiency assessment.

\section{References}

1. Zagorka O.M. Methodical provisions for assessing the survivability of the anti-aircraft missile system from the action of its elements to defeat the enemy / O.M. Zagorka, V.V. Koval, I.O. Zagorka // Collection of scientific works of Kharkiv University of the Air Force. - 2017. - № 4. - P. 1216. 2. Gorodnov V.P. Modeling of combat operations of troops (forces) of air defense and information support of their management processes (theory, practice, history of development) / V.P. Gorodnov [etc.]; Kharkiv Military University - Kharkiv.: KhMU, 2004. - 410 c. - ISBN 966601-071-2. 3. Gogonyants S.Y. Improved analyticalstochastic model of anti-aircraft combat anti-aircraft missile system /, V.P. Gorodnov, S.Y. Gogonyants // Modern information technologies in the field of security and defense // NUOU - K, 2010. - №2 (8) - P. 47 - 54. - Access mode: http://nbuv.gov.ua/UJRN/sitsbo_2010_2_3.

4. Gogonyants S.Y. Advanced method for assessing the effectiveness of air defense of troops and facilities [Text] / G.S. Stepanov, S.Y. Gogonyants // Materials of the scientific-practical seminar "Information technologies in the military sphere", Thesis. ext. - Kyiv: NUOU, 2010. - P. 4952. 5. White Book of the anti-terrorist operation in eastern Ukraine (2014-2016) / (edited by I. Rusnak) - Kyiv: Ivan Chernyakhovsky National University of Defense of Ukraine, 2017. - 162 p. - ISBN 978-617-7187-21-8. 6. Official website of Deutsche Welle. The war between Armenia and Azerbaijan over Karabakh: which brought a month of fighting. - Access mode: https://www.dw.com/uk/viinavirmenii-ta-azerbaidzhanu-za-karabakh-shcho-prynis- misiats-boiv/a-55423675 (15.10.2021). - Name from the screen. 7. Bernadsky B.V. International conflicts: a course of lectures / B.V. Bernadsky. - K.: SE:Publishing House "Staff", 2012. - 366 p. - ISBN 978-617-02-0088-4. 8. Analysis of forms and methods of application of the Land Forces in modern conditions, which affect the development of weapons, means of technical support, training of technical specialists [Electronic resource] / M.M. Seredenko, R.V. Kuzmenko, R.V. Khorev, L.M. Kizlo, - Lviv: NASV, 2017. - Access mode: https://www.ukrmilitary.com/2017/09/analy sis-forms-and-methods.html (15.05.2021). - Name from the screen. 9. Combat Charter of the Air Defense Forces of the Land Forces, Part III - K: CSR of the Armed Forces of Ukraine, 2016. - 142 p. 10. Gorbachev K.M. Improved system of indicators of the effectiveness of the air defense system of the military formation of the tactical level in the offensive battle / K.M. Gorbachev // Journal of Scientific Papers "Social Development and Security", Vol. 11, no. 5, October, 2021, P. 81-89. DOI: https://doi.org/10.33445/sds. 2021.11.5.8, ISSN 2522-9842. 11. Spartak Hohoniants. Development of the survivability indicators forecasting method of the special-purpose system executive element based on analytical and stochastic simulation of a conflict situation. / Spartak Hohoniants, Kostiantyn Horbachov, Dmytro Chopa, Oleksii Kilmeninov, Anatolii Loishyn // Eastern-European Journal of Enterprise Technologies. 2021. Vol. 3 No. 4 (111). P. 14-23. DOI: https://doi.org/10.15587/1729-4061.2021.233899. 